\title{
Feasibility Study of Modified Press Machine For Production Genteng Efficiency in Small Enterprise
}

\author{
Peni Sawitri, Supriyono, and Eko Hartanto
}

\begin{abstract}
Kebumen's tile industry with Sokka tile product name has long been known in Central Java Indonesia. Unfortunately tile Sokka still has some weaknesses such as the traditional production techniques, innovation is not optimal, mixed household finances by the financial industry, the traditional management, no firm association container tile factory and there is no standardization of tile prices and no government support. This study aims to conduct feasibility study of modification efforts tile press machine by analyzing the five aspects including financial aspects, production and operational aspects, market aspects, social and economic aspects. Results of the study showed that, using cost benefit ratio analysis, it was found that there was a significant increase in financial benefits; from production and operational point of views there were a significant product quality improvement (i.e. production cost savings with the modification of press machines, among other things in terms of production time and increasing production capacity); innovation and product variety seemed to be of importance to fill a wide open market opportunities; and manufacturing modified tile roof machine provided a positive impact on rural incomes and employment.
\end{abstract}

Index Terms-Modified tile press machine, financial performance and market opportunities.

\section{INTRODUCTION}

Kebumen's tile industry with Sokka tile product name has long been known in Central Java Indonesia. Its name is equated with other famous tile industry, such as tile Jatiwangi origin Majalengka, West Java. Unfortunately tile Sokka still has several weaknesses, among others, the traditional production techniques, from raw material processing techniques, printing techniques, drying techniques to combustion technique. Although this industry also has advantages that are able to support some of the residents and make market opportunities that can increase Kebumen's income.

Tile industries also rely on these natural resources, externally quite positive because Kebumen bring the name of national tile in the market, especially in Central Java, East Java, West Java, even partially. However, internally there are advantages and disadvantages. The surplus is because the results are able to support most of the population, while the shortcomings since the raw material of clay that cannot be updated.

Because the tile industry in the region Kebumen Sokka is a

Manuscript received November 17, 2011; revised November 23, 2011. Peni Sawitri is with the Economics Faculty in Gunadarma University. Supriyono is with the Industrial Technology Gajah Mada University. Eko Hartanto is with the IISIP Jakarta, Indonesia small enterprise, then from below the existing level of price competition among small enterprises with each other. Then, for marketing to Yogyakarta and surrounding areas there is no region of origin tile industry that are cheaper, although its quality is still below the tile origin Kebumen Sokka. Similarly, for marketing to the East Java region in addition to competition with the local tile industry is also expensive transportation costs. Especially for marketing to the region of West Java to Jakarta, where in the region already is dominated by Jatiwangi tile industry. But the name of tile Sokka still be calculated in the home industry. Therefore we are interested to conduct research, to try to get Sokka tile industry in the region still continuing and can even compete in the national industry.

Roof tile production process Kebumen Sokka initially faced some obstacles in the use of manual press machines such as the traditional production techniques, innovation is not optimal, mixed household finances by the financial industry, the traditional management, no firm association container tile factory and there is no standardization of tile prices and no government support. In an effort to minimize the constraints above and to be able to realize new business based on knowledge and technology. Therefore a comprehensive study needs to be done to conduct a feasibility study on the use of modifications in order to streamline the production of press machines in tile industry.

Modification of tile press machine with a mechanical drive system mounted transverse screw with a pulley drive side, which allows the pressing of tiles made by one person. This study aims to conduct feasibility study of modification efforts tile press machine by analyzing the five aspects including financial aspects, production and operational aspects, market aspects, social and economic aspects [1].

Investment in a business or project, either for a new business or expansion of existing businesses, usually tailored to company objectives and forms of business entities [2]. For company objectives can be done that before investing, in general, they have done a study to assess whether the investment will be invested to provide benefits or not. This study is known as the feasibility study, business is an activity to learn in depth about a company or business running, in order to determine the possible or not the business is run [3]-[4]. A Business Feasibility Study can be defined as a controlled process for identifying problems and opportunities, determining objectives, describing situations, defining successful outcomes and assessing the range of costs and benefits associated with several alternatives for solving a problem. [5]-[6]. The Business Feasibility Study is used to support the decision-making process based on a cost benefit analysis of the actual business or project viability. 
Kebumen tile production machine in most regions using traditional screw press machine. Where the prime mover in the form of large pulley that drives the screw to press the printer mats or tiles, which are driven by human power. Pressing machine pulley drive system made of solid cast iron with a diameter of $100 \mathrm{~cm}$, so that feels heavy to operate it is usually driven by 2 people manually. This research was conducted to facilitate operational way tile pressing machine. The press machine is expected to be modified in operation will be much lighter and pulley only played by one person. Compression strength resulting from the pressing machine is expected the same as before, because it still uses the screw drive system but with a modified system of selection of mechanical and lighter materials. Thus the research problem can be formulated as follows: Is the modification of hydraulic tile feasible to be implemented?

\section{RESEARCH METHOD}

The study was conducted by a modification of tile industry offer press machine in order to strengthen the technology by first conducting a feasibility study on the modification of industrial tile press machine in the following ways and methods of benefit-cost ratios. To assess whether or not a viable business can be viewed from various aspects. Aspects considered in the feasibility study covering the legal aspects of business, market and marketing aspects, financial aspects, technical aspects / operational, management and organizational aspects, economic aspects and social aspects of environmental impact. The five aspects can be observed and investigated with the following details [4]e.g :

1) Markets and Marketing aspects: whether the product can be sold? By examining this aspect of the demand components of tile, tile buyer, the tile industry competition, the promotion is done, distribution and pricing.

2) Financial aspects will determine the prospects for investment through the calculation of the expected costs and benefits, to compare the revenue expenditure, such as the availability of funds, cost of capital, ability to refinance the project funds within the allotted time so that the project (press machine modifications) are relevant to carried out.

3) Technical Aspects of Production and Operations: whether the business can be set-up with innovation? This is done by considering the location, the source of raw materials, labor, tools and machines used, transportation to distribution, if any communication, environment and infrastructure that support the production process.

4) Economic and social aspects are expected to provide positive impacts such as providing opportunities to increase income communities and provide income in the form of revenue for local governments.

Methods of data collection using questionnaire survey to the tile industry employers about work systems old tile pressing machine and to know aspects of market, financial, and socioeconomic aspects. In addition, the review will be carried out directly in the field of production processes from early stages to the final stage. As the number of tile industry employers is too many to be included in this research, a sample was chosen from the population. Sampling technique deployed is purposive sampling. The criteria which was used to choose the sample was having home industry of tile more than three years. The samples were selected from five districts of the central tile industry in the District of Kebumen are Sruweng, Pejagoan, Adimulyo, Klirong and Kutowinangun. This research was conducted in only two districts namely Pejagoan and Klirong with the consideration that has more tile industry from other industries.

Data were analyzed using comparative techniques, which is to compare the cost of production before and after modification of press machine, in order to obtain data for use in the period after analysis of the data recovery method and the relationship benefit-cost ratios as a tool of analysis in one of the aspects of finance, in addition to investigate other aspects, such as aspects of financial, market, technical aspects of production and operations and the socio-economic aspects.

\section{RESUlTS AND ANALYSIS}

Cost-benefit analysis was performed by comparing the costs of production before pressing machines handled after the press of changes, as shown in TABLE I. This calculation is done by assuming the capacity of tile furnace as much as 17000 pieces.

TABLE I: COMPARISON OF PRODUCTION COST

\begin{tabular}{|c|c|c|}
\hline Production Cost & Before & After \\
\hline Raw Material costs @ Rp $150 \times 17.000$ & $\mathrm{Rp} 2,550,000$ & $\mathrm{Rp} 2,550,000$ \\
\hline Fixed Labor costs @ Rp 15.000 & $\mathrm{Rp} 2,310,000$ & $\mathrm{Rp} 1,530,000$ \\
\hline Overhead costs @ Rp 25 x 17.000 & Rp425,000 & Rp425,000 \\
\hline Tile drying costs @ Rp 15 x 17.000 & Rp255,000 & Rp255,000 \\
\hline The cost of the combustion process & Rp750,000 & $\operatorname{Rp} 750,000$ \\
\hline The cost of firewood & $\mathrm{Rp} 3,500,000$ & Rp3,500,000 \\
\hline Total Production Costs & Rp9,790,000 & Rp9,010,000 \\
\hline Sales @ Rp $750 \times 16.000$ & Rp12,000,000 & Rp12,000,000 \\
\hline Net Profit & Rp2,210,000 & Rp2,990,000 \\
\hline
\end{tabular}

Source : Primary Data

As shown in TABLE I, there is increased profit of $\mathrm{Rp}$ 780,000 , - after modification press machine. Increase in profit is because there are cost savings of workers. After the modified press machine will provide the following benefits:

- Reduce the number of workers from 7 people to 6 people

- Increase the amount of production from $700 \mathrm{~s} / \mathrm{d} 800$ into 1000 tiles per-day

- Target achievement tile production requires a shorter time than 22 days was reduced to 17 days.

- Tile pressing labor costs will be reduced with details @ Rp $15.000 \times 6$ people $\times 17$ days $=\operatorname{Rp} 1.530 .000,-$ from before modification press machine.

- With the reduction in the cost of pressing the tile is expected to reduce the production cost of about 8 to $10 \%$, which would add to profits.

Thus, based on cost and benefit analysis of the press machine proper modifications are made to improve the performance of tile production process. Even this result is strengthened by examining and reviewing aspects of the 
feasibility study of the financial aspects of the business, markets, and the socio-economy, presented in the following way:

\section{Results Analysis of Financial Aspects}

As shown in TABLE II, only 15 home industries of tile were successfully interviewed.

TABLE II: INITIAL CAPITAL TILE INDUSTRY

\begin{tabular}{|l|r|}
\hline Capital & Total Industry \\
\hline$<\mathrm{Rp} 10.000 .000,-$ & 3 \\
\hline $\operatorname{Rp} 10.000 .000-\operatorname{Rp~} 15.000 .000$ & 8 \\
\hline$>\operatorname{Rp} 15.000 .000$ & 4 \\
\hline Source : Primary Data &
\end{tabular}

From the table above is known that most of the tile industry start their business with capital of Rp 10,000,000 to Rp 15,000,000, -. After 2 or 3 years they have experienced a significant increase in assets as presented in the following TABLE III.

TABLE III: MARKET VALUE ASSETS

\begin{tabular}{|l|r|}
\hline Market Value of Business Assets & Total Industry \\
\hline $\operatorname{Rp} 1.000 .000 \mathrm{~s} / \mathrm{d}<\mathrm{Rp} 10.000 .000$ & 7 \\
\hline $\operatorname{Rp} 10.000 .000 \mathrm{~s} / \mathrm{d}<\mathrm{Rp} \mathrm{50.000.000}$ & 7 \\
\hline $\operatorname{Rp} 50.000 .000 \mathrm{~s} / \mathrm{d}<\operatorname{Rp} 500.000 .000$ & 1 \\
\hline
\end{tabular}

Source : Primary Data

Tile industry in the two districts of Kebumen have a good turnover and have a promising business opportunity is as shown in the table below.

TABLE IV: SALES TURNOVER

\begin{tabular}{|l|r|r|}
\hline Total Sales Turnover & $\mathbf{2 0 0 8}$ & $\mathbf{2 0 0 9}$ \\
\hline$<\operatorname{Rp} 120.000 .000$ & 2 & 1 \\
\hline $\operatorname{Rp} 120.000 .000 \mathrm{~s} / \mathrm{d}<\mathrm{Rp} 150.000 .000$ & 2 & 3 \\
\hline $\operatorname{Rp} 150.000 .000 \mathrm{~s} / \mathrm{d}<\mathrm{Rp} 180.000 .000$ & 1 & 0 \\
\hline $\operatorname{Rp} 180.000 .000 \mathrm{~s} / \mathrm{d}<\mathrm{Rp} 210.000 .000$ & 4 & 5 \\
\hline $\operatorname{Rp} 210.000 .000 \mathrm{~s} / \mathrm{d}<\operatorname{Rp} 240.000 .000$ & 1 & 2 \\
\hline $\operatorname{Rp} 240.000 .000 \mathrm{~s} / \mathrm{d}<\operatorname{Rp} 270.000 .000$ & 4 & 1 \\
\hline $\operatorname{Rp} 270.000 .000 \mathrm{~s} / \mathrm{d}<\operatorname{Rp} 300.000 .000$ & 1 & 3 \\
\hline
\end{tabular}

Source : Primary Data

TABLE IV seems all the tile industry has increased sales in the last two years (2008 and 2009), although there are some who do not. Revenues from sales in a year that can be achieved by the tile industry is between Rp 180 million to 210 million rupees,--. On the whole financial aspect shows a promising opportunity to continue the tile industry with hydraulic modification that is feasible to be implemented.

Results Analysis of Market Aspects

Tile name Sokka still be calculated in the home industry, especially by looking at big market opportunities as presented in the following table.

\section{TABLE V: MARKET OPPORTUNITIES}

\begin{tabular}{|l|r|}
\hline Market Opportunities & Percentage \\
\hline Sufficient capital available & $80 \%$ \\
\hline Extensive marketing & $87 \%$ \\
\hline Labor availability & $27 \%$ \\
\hline Innovation in product, marketing and process & $53 \%$ \\
\hline Raw material availability & $100 \%$ \\
\hline Good business management & $40 \%$ \\
\hline
\end{tabular}

Source : Primary Data

Tile industry in the two districts (Pejagoan and Klirong ) have a large enough market opportunity, especially seen from the benefits of the availability of raw materials and capital and market opportunity that is wide enough as shown in the table above. It thus can be enhanced with a variety of marketing efforts that have been done as shown in the following table.

TABLE VI:MARKETING EFFORTS

\begin{tabular}{|l|r|}
\hline Efforts to increase product sales & Percentage \\
\hline Exhibition & $40 \%$ \\
\hline Lower selling prices & $40 \%$ \\
\hline Sales discount & $53 \%$ \\
\hline Sales on credit & $93 \%$ \\
\hline
\end{tabular}

Source : Primary Data

TABLE VI shows the various marketing efforts that were made by the fifteen tiles respondents in this study, the majority of marketing efforts through sales discount and the sale of credit. This is possible because most of the population in rural districts like buying on credit.

Results Analysis of Technical Aspects of Production and Operations

All the tile industry in the two districts using the same raw material that is made of clay that can not be renewed, and auxiliary raw materials from the land of Sand and Firewood. They have the advantage of all the raw materials and auxiliary materials is derived from one district, one village and one district the same as the workforce is also derived from the same village and district. Various advantages can be seen in the TABLE VII.

Tile production process currently undertaken by small industries in the region Kebumen Sokka tile is as follows:

- Phase I, (Material): Where the base material in the form of pure clay and sand sometimes mixed with soil or sand beaches.

- Phase II (Basic Materials Processing): That is the processing of clay with water, thoroughly trampled the soil sometimes mixed with sand or sea sand.

- Phase III, (Printed Materials Processing): The basic ingredients that have been processed earlier, mashed with molen the ground as much as 2 times that are made in the form of a square box with a size that has been adjusted.

- Phase IV, (Pressing): That is the process of printing a square-shaped molding material by using a manual press machines.

- Phase V, (Drying): That is the process of drying the tile that has been pressed with aerated on the shelves are made compound, then dried or heated by the sun.

- Phase VI, (Combustion): That is the burning process which has been dried sun-dried tiles, which burned in the furnace (tobong) about 10 hours.

After the tile is finished burned in the furnace, and then allowed to cool prior to further removed from the furnace and is ready for market. Innovation in production needs to be done by modifying one tile press machine so that it can increase production efficiency. The study was implemented 
to facilitate operational way tile pressing machine.

The press machine is expected to be modified in operation will be much lighter and pulley only played by one person. Compression strength resulting from the pressing machine is expected the same as before, because it still uses the screw drive system but with a modified system of selection of mechanical and lighter materials.

TABLE VII: INDUSTRIAL PRODUCT EXCELLENCE ROOF

\begin{tabular}{|c|c|}
\hline $\begin{array}{c}\text { Product Advantages Compared to Similar } \\
\text { Products }\end{array}$ & Percentage \\
\hline Number of Production of Large and Varied & $7 \%$ \\
\hline Product variations & $7 \%$ \\
\hline Type and Quality of Product & $13 \%$ \\
\hline The number of large production & $13 \%$ \\
\hline Quality of refined products & $27 \%$ \\
\hline Product quality is smooth and mild & $7 \%$ \\
\hline Product quality is smooth and thick & $7 \%$ \\
\hline Quality products more presentable & $13 \%$ \\
\hline Smooth completion & $7 \%$ \\
\hline
\end{tabular}

From TABLE VII above it appears that most tile industry recognizes superior because of the quality of the resulting product is very smooth, neat and in large numbers, but they acknowledge that the range of tile products do not have much range, on average most only produce one type of tile.

\section{Results Analysis of Socio-Economic Aspects}

The results of the economic and social aspects of this show the positive impact such as providing opportunities to increase income communities and provide income in the form of revenue for local governments and existing natural resource management (as raw material for tiles) is better. These results are illustrated in the following table.

TABLE VIII: POSITIVE IMPACT TILE INDUSTRY

\begin{tabular}{|c|c|}
\hline $\begin{array}{c}\text { Positive impact on the surrounding } \\
\text { community }\end{array}$ & Percentage \\
\hline Opening employment opportunities & $100 \%$ \\
\hline Provide guidance to workforce & $27 \%$ \\
\hline Increasing the income of the community & $93 \%$ \\
\hline Promoting other similar business & $7 \%$ \\
\hline Utilization of local resources & $73 \%$ \\
\hline Source Primary Data
\end{tabular}

From TABLE VIII appears that the greatest impact with the roof tile industry in both sub Pejagoan and Klirong is this industry to open jobs for local residents in addition to increased income communities in both these districts. Fitting these results open the opportunity for the tile industry for more active and valued by the Local Government Kebumen be able to compete on a national level.

With the press machine are modified in this study are expected in the operation will be lighter and pulleys sufficiently rotated by one person. Compressive force resulting from the pressing machine in this study also expected the same as the old one, because it uses a screw drive system but with a modified mechanical systems and the selection of lighter materials. The question then arises why not use an automated pressing machine with hydraulic drive (pneumatic or electric)?. Since the orientation of this research is to small enterprises or home industries that use the operational costs are small, simple but effective equipment.
Meanwhile the price of an automated pressing machine with hydraulic drive (electric) was expensive and require an electric drive with a large power and specialized professional personnel too.

\section{CONCLUSION}

Tile industry in the two districts namely Pejagoan and Klirong have an excellent business opportunity with the demonstrated feasibility study analysis of the financial aspects of roof tile industry, market, economic and social aspects.

The results of the feasibility study showed an increase in the financial aspect profit of Rp 780000 in hopes of reducing production costs by about $10 \%$. From there the operational aspects of production and production cost savings with the modification of press machines, among other things in terms of production time and increasing production capacity. Thereby increasing the effectiveness of tile production in the home industry in Kebumen. Aspects of the market shows a great opportunity when the innovation of diverse types of production can be increased and the resulting economic and social aspects indicate a very positive impact with increased incomes and employment opportunities expanded.

Referring to the feasibility study results of hydraulic modifications to the tile industry in Kebumen this then there are some things that can be recommended include the following:

a. Market Development : the effort to increase sales of existing products with new markets.

b. Product Development: should the effort to offer new products or improved existing products on the market today.

c. Market Penetration: need an effort to increase sales of products that are already owned by them through more aggressive marketing mix, and perform Diversification is an effort to diversify the business.

\section{ACKNOWLEDGMENT}

1) We thank the Directorate General of Higher Education Institutions (DIKTI-Indonesia) through competitive grants program (PHKI) which has funded this research to be undertaken.

2) We thank the owners of tile business and workers who have taken the time to be interviewed and his willingness to be respondents in this study.

\section{REFERENCES}

[1] H. Hoagland and L. Williamson, Feasibility Studies, Kentucky, University of Kentucky, 2000

[2] G. J. William, Investment, Prentice Hall Inc, 1995

[3] K. Jakfar, Studi Kelayakan Bisnis Edisi Kedua, Kencana Prenada Media Group, Jakarta, 2007

[4] R. Supriadi, Desain Studi Kelayakan, 2008 Online available: http://ekonomiunair.wordpress.com

[5] A. Thompson, Business Feasibility Studies: Dimensions of Business Viability, Perth, Best Entrepreneur, 2003

[6] A. Thompson, Business Feasibility Outline, Perth, Entrepreneurship and Business Innovation, 2005. Online available: http://www.rochester.edu/Business_Feasibility_Study_Outline.pdf 